\title{
DETERMINATION AND SUPPORT AS SUCCESSFUL FACTORS FOR SMOKING CESSATION
}

Isabel Cristina Echer1

Sérgio Saldanha Menna Barreto

Echer IC, Barreto SSM. Determination and support as successful factors for smoking cessation. Rev Latino-am Enfermagem 2008 maio-junho; 16(3):445-51.

This study aimed to analyze determination and support as successful factors for smoking cessation. Qualitative study in which 16 individuals from Porto Alegre, Brazil, who had ceased smoking for more than six months, with score $\geq 5$ according to Fagerström scale, were interviewed. Information was examined through Content Analysis according to the following steps: pre-analysis, material investigation and result treatment. Smoking cessation was a consequence of a group of factors, with determination (the will to cease smoking and the difficulty to cease smoking) and the received support (occupational; family; social, and spiritual, and through a specific course and support groups) as the focus of this article. The results suggest that the smoker's determination to cease smoking together with the support of society segments and the benefits from that are helpful factors in the smoking cessation process.

DESCRIPTORS: smoking; smoking cessation; qualitative research

\section{LA DETERMINACIÓN Y EL APOYO COMO FACTORES DE ÉXITO EN EL ABANDONO DEL TABAQUISMO}

Este estudio tuvo como objetivo analizar los factores que contribuyen para obtener éxito en abandonar el tabaquismo. Es un estudio cualitativo, en el cual fueron entrevistados 16 individuos de Porto Alegre, en Brasil, que dejaron de fumar hace más de seis meses, con puntuación $\geq 5$ de la escala de Fagerström. Las informaciones fueron examinadas por un Análisis de Contenido, por medio de las etapas de análisis, examen del material y tratamiento de los resultados. El abandono del tabaquismo es el resultado de un conjunto de factores, siendo el foco de este artículo la determinación (querer parar y la dificultad de parar de fumar) y el apoyo recibido (profesional, familiar, social y espiritual). Los resultados sugieren que la determinación del fumador de querer parar de fumar, aliada al apoyo de segmentos de la sociedad son factores que ayudan de forma significativa para el proceso de abandono del tabaquismo.

DESCRIPTORES: tabaquismo; cese del tabaquismo; investigación cualitativa

\section{DETERMINAÇÃO E APOIO COMO FATORES DE SUCESSO NO ABANDONO DO TABAGISMO}

Este estudo teve por objetivo analisar fatores que contribuem para o sucesso no abandono do tabagismo. Estudo qualitativo, no qual foram entrevistados 16 indivíduos de Porto Alegre, RS, Brasil, que pararam de fumar há mais de seis meses, com pontuação $\geq 5$ pela escala de Fagerström. As informações foram examinadas através da Análise de Conteúdo, por meio das etapas de pré-análise, exploração do material e tratamento dos resultados. O abandono do tabagismo resultou de um conjunto de fatores, sendo foco deste artigo a determinação (querer parar e dificuldade de parar de fumar) e o apoio recebido (profissional, familiar, social e espiritual). Os resultados sugerem que a determinação do fumante de querer parar de fumar, aliada ao apoio de segmentos da sociedade são fatores que auxiliam de forma significativa o processo de abandono do tabagismo.

DESCRITORES: tabagismo; abandono do hábito de fumar; pesquisa qualitativa

${ }^{1}$ RN, Ph.D. in Medical Clinic, Adjunct Professor, Rio Grande do Sul Federal University School of Nursing, Brazil, e-mail: isabel.echer@terra.com.br; ${ }^{2}$ Postdoctoral degree in Health Sciences, Full Professor, Rio Grande do Sul Federal University School of Medicine, Brazil; Head, Pneumology Service, Hospital de Clínicas de Porto Alegre, Brazil, e-mail: smenna@terra.com.br 


\section{INTRODUCTION}

Smoking is a global public health problem, affecting the life of smokers and individuals exposed to smoking and environmental pollution. Around 4 million people die annually in the world of smokingrelated diseases. If adequate measures are not taken, in around 2020 smoking will correspond to 10 million deaths/year. From these deaths, 7 million will occur in developing countries ${ }^{(1)}$.

The possibilities to contribute to the smoking cessation process include: cognitive-behavioral approach, pharmacotherapy, clinical monitoring, therapeutic groups and family support. Since the 1980s, the importance of advertising in the media the smoking harms, the advantages of being an exsmoker and the environmental damages involved in the process has been emphasized, which may also help the cessation and discourage smoking start ${ }^{(2)}$. Although around $80 \%$ of the smokers wish to quit smoking, only about 3\% actually stop without help annually, which demonstrates the role of health professionals and the society in the promotion of incentives that encourage smoking cessation ${ }^{(3)}$.

The elaboration of this project was encouraged by the belief that knowing and understanding the factors associated with smoking cessation may help increment smokers' adhesion to the decision of stopping smoking and reduce the number of young people that start smoking.

Although frequent campaigns are made to encourage smoking cessation, little is known about the real reasons that make a person quit. Based on that, a study was developed ${ }^{(4)}$ to investigate the successful factors for smoking cessation, which identified that smoking cessation was a consequence of a group of factors (determination, received support, social restrictions to smoking, information on smoking harms, clarification campaigns, utilization of strategies and benefits related to smoking cessation). This articles analyzes the contribution of smoking cessation determination and received support in the smoking cessation process.

\section{METHODOLOGY}

An exploratory-descriptive qualitative study in which 16 individuals from Porto Alegre, RS, were interviewed, recruited from the community through placards, advertising among friends and invitation from participants. The definition of this number occurred through data saturation ${ }^{(5)}$. In order to be included in the study, the individual should have ceased smoking for more than six months and show dependence score $\geq 5$ according to Fagerström scale ${ }^{(6)}$, which consists in a questionnaire of six questions, whose scores range from 0 to 10 . The dependence degree is classified according to the total score: very low ( 0 to 2 ); low ( 3 and 4 ); medium (5); high (6 and 7 ) and very high ( 8 to 10 ).

The project was approved by the Research Ethics Committed of the Hospital de Clínicas de Porto Alegre. Everyone agreed to participate in the study by signing the Informed Consent Term. The ethical principles were respected, according to Resolution 196/96 of the National Health Council.

The semi-structured interviews, conducted by the main author at the participants' homes or work places, presented the main question: "What factors contribute to a successful smoking cessation?"

The results were analyzed by the Content Assessment ${ }^{(7)}$, involving data exploration, systematization and operationalization, classification of statements into units of meaning, ending up with interpretation of categories and possible explanations regarding the investigated phenomenon.

Data confirmation was performed through pair crosscheck mechanism and the participation of an external reviewer ${ }^{(5)}$ that performed interview reading and analysis and elaborated an interpretation summary, obtaining the same results found by the researcher.

In order to keep data secrecy, the declarations were identified by numerical codes that distinguish the interviews and Fagerström scale score (for instance: E1F5 - interviewee 1; scale score 5).

\section{RESULTS AND DISCUSSION}

The interviewees were between 24 and 62 years old and presented different occupations (housewife, caretaker, printing technician, actress, student and medium school level and university professor, administrator, laboratory advertiser, massager, administrative assistant and mechanic assistant) and schooling levels, from complete fundamental to post-graduation level. They started smoking when they were between 11 and 22 years 
old. The smoking habit duration ranged from 9 to 42 years and the amount of cigarettes a day was between 15 and 40, with Fagerström scale score from 5 to 10, mean score: 7.4 .

The interviewees ceased smoking through different forms: professional intervention and bupropion (E2F7, E3F10, E6F10, E7F10, E9F9), professional intervention and nicotine gum (E10F10), participation in support groups conducted by a health professional (E2F7, E3F10, E10F10, E11F5, E14F5) and the others did not go through any specific treatment. Regarding previous attempts to cease smoking, they had tried once (E3F10, E4F7, E10F10, E11F5), twice (E2F7, E7F10, E9F9, E15F8, E16F8), three times (E5F6, $E 12 F 5, E 13 F 6, E 14 F 5)$ and the others had not tried at all. The results show that the higher the dependence, the higher the search for professional help and drug utilization. The abstinence period, on the interview occasion, ranged from 8 months to 4 years.

Determination to cease smoking

In this study, determination refers to the will that made smokers keep their smoking cessation decision, despite the adversities that included the remaining smoking will and the cigarette importance in the smoker's life. The interviewees' declarations revealed the difficulty they faced in the smoking cessation process and the determination required to remain distant from cigarettes. This category was divided into two subcategories: will to cease smoking and difficulty to cease smoking.

- Will to cease smoking

The interviewees considered as essential the smoker's decision to cease smoking, without which the commitment to the change does not occur, even with family and professional help and drug utilization.

I decided I would quit, I quit and that was all... The most important thing is your will-power. E1F5

If there's no strong will-power, you will never get to do it, even with a treatment ... E5F6

You must be determined, with strong will-power, because the drug helps, but it doesn't work alone. E6F10

I guess my determination was persevering, and second, the physicians' warnings... If I hadn't had strong will-power, I wouldn't have done it. E10F10

To some interviewees, the change was preceded by specific situations and/or events that made them see themselves and the smoking habit differently, where the cigarette appears as a problem to be solved. When asked about the change reason, most of them answered that they simply made the decision. The declarations show that without the individual decision, the smoking cessation process does not occur, and that this behavior change is associated with reflection, will and personal determination. The professional and family and social groups may encourage, support and help in this process, but the decision to change must be assumed by the individual.

According to the interviewees, their determination to cease smoking would have been encouraged by several factors (Table 1 ).

Table 1 - Reasons that contributed to the interviewees' smoking cessation, presented according to the Dominance Coefficient (DC). Porto Alegre, RS, 2006

\begin{tabular}{lc}
\hline \multicolumn{1}{c}{ Indicators } & DC \\
\hline Will to change/determination & 80 \\
Cigarette interference in social life and laws that restrict smoking & 35 \\
Influence of close people & 35 \\
Esthetical and smelling sense & 30 \\
Health harms & 26 \\
Health concerns & 23 \\
Life appreciation & 13 \\
Health problem observation & 10 \\
Knowing health harms & 9 \\
Getting annoyed about cigarette & 7 \\
Shame/frustration of being a smoker & 7 \\
Money & 6 \\
Health professional & 4 \\
Media campaigns & 4 \\
Spiritual support & 2 \\
Acting as a smoker on stage & 1 \\
Participation in anti-smoking commission & 1 \\
Age & 1 \\
\hline
\end{tabular}

These reasons reveal mainly the need of individual will to change/determination and influences of other people on the smoking cessation decision, such as professionals, family, friends and social communication means, suggesting the importance of the community's role in individual motivation. It emphasizes the assumption that the motivation to change does not lie only inside the individual, but it involves an interpersonal context.

The results of this study agree with those of other studies that also consider as essential emphasizing the smokers' motivation and working with their family and friends to encourage them in their decision ${ }^{(8)}$. Motivation is a paramount factor and 
the health professionals' action should support smokers for smoking cessation and alert them to smoking risks and cessation benefits ${ }^{(9)}$.

Other studies state that personal motivation is one of the most important factors in smoking cessation and is interconnected with a number of hereditary, psychological, physiological and environmental variables. Making the individual start thinking of quitting smoking is a great step for him/ her to effectively cease smoking ${ }^{(8)}$. The results of this study show individual motivation as one of the main factors towards cessation. For this reason, it is necessary to develop actions to encourage and support smoking cessation, which is the best and cheapest form of prevention, treatment and healing of several diseases associated with smoking, aiming at improved quality of life.

- Difficulty to cease smoking

The interviewees reported that they have not restarted smoking due to the intense suffering during the smoking cessation process, which involved aggressive relationship with people, not feeling well with themselves, feeling of failure and the indication of restarting when simply placing a cigarette in between their lips.

I won't smoke again, I'll never smoke again. Not because smoking is bad, but to avoid the suffering I went through when I stopped. E2FY

I can't place a cigarette in between my lips, if I do that, I will want to smoke. Do you know why I do that? Because it's very difficult to stop smoking ... E3F10

Those three first weeks were terrible. I was fighting with the dog, the walls, with everything, it was horrible ... You've got to be persistent. E10F10

For the interviewees, keeping the control over their behavior between having pleasure to smoke and recognizing smoking harms was described as a difficult phase to go through, and for this reason, determination, responsibility for the change and support are required.

These findings validate the study, in which many patients report great individual and family suffering and little tolerance to the abstinence syndrome, which makes smoking cessation resolution more difficult ${ }^{(8)}$. The interviewees said that professional intervention and drug utilization are important in this phase, in order to minimize the suffering caused by the syndrome of abstinence, this way making smoking cessation more successful.
Some of the interviewees had already experienced in previous attempts to cease smoking the restarting situation, a fact that encouraged them to search for professional help to cease. Literature indicates that restarting should not be considered as a failure, but as a moment of reflection on the factors that made them restart, and better prepare them for the next attempt, since most smokers try to stop three to four times on average until they definitively cease ${ }^{(10-11)}$.

The cognitive-behavioral approach may help support smokers, as it combines cognitive interventions and training of behavioral skills, aiming at cessation and restart preventions ${ }^{(9-10)}$. The adequate approach, according to the interviewees, favored their behavior change.

Regarding the suffering the interviewees went through, it was possible to notice the great satisfaction and pride demonstrated for having ceased smoking, an action that has brought benefits to their lives.

Received support

The interviewees reported the need for professional, family, social and spiritual support, conditions that constituted factors that helped overcome the nicotine dependence. This situation agrees with the literature references, which state the smoker needs to create an identification link with a certain person, who could be a brother or sister, relative, neighbor, nurse, physician, etc., to help him/ her in this process ${ }^{(12)}$.

This category was subdivided into three subcategories: intervention of qualified professionals and drug utilization, specific course and support groups, family, social and spiritual support.

- Intervention of qualified professionals and drug utilization

The professional intervention was described as an important factor during smoking cessation, and in some situations, the utilization of drugs to help in this process.

The interventions of health professionals often seek to fulfill the individual's supposable lack of knowledge regarding what caused a certain disease. Innumerous studies have demonstrated the association of smoking with certain diseases. However, although this risk factor may be eliminated, health services have not made people cease smoking(12), which reflects the people's difficulty to stop smoking. 
The fact that smoking cessation interventions have not been integrated into and made available in health routines, as well as the unbelief demonstrated by some professionals regarding nicotine dependence treatments, constitute some obstacles for smoking cessation $^{(8,10)}$.

However, the interventions in this study revealed their potential, according to the declarations that evidence the importance of professional intervention and the benefits of drug utilization.

I wouldn't do it alone and then I decided to search for help. I had the intervention of a professional. Drugs help a lot, they eliminate the desperation feeling ... But we have to stipulate a deadline, the cigarette must disturb us ... E2F7

I wouldn't have done it with just my efforts. I searched for a friend who works with smoking cessation to support me. She prescribed me the medicine. It was essential, 5 days later I didn't feel like smoking again and then I stopped buying cigarettes. E7F10

The physician said: when you decide to do that, you will never stop trying, die trying, but don't quit, go for what you want... E9F9

Their statements reveal that the support of a prepared professional seems to be of great importance to overcome stages such as physician visit returning, correct drug utilization and asking for additional help if desired. Besides, they reflect the professionals' statements in their approaches to stipulate a deadline and keep themselves determined, which seems to have influenced in such way to mobilize and help the smokers.

It is believed that the approach strategies should value the specific aspects of age, focusing the lifestyle and the quality of life and reinforce attitudes and skills to face the situations that lead to smoking.

The challenge is to find out and understand how to help strengthen the motivation to change, and this is an important part of the individual assessment $^{(13)}$. Based on the declarations, it is possible to infer that it should not be assumed that smokers will consider harms or benefits the same way as nonsmokers, as the values are different and consequently the approaches must be distinct.

A treatment against dependence has the cognitive-behavioral approach as a central aspect, which combines cognitive interventions and training of behavioral skills aiming at cessation and restart prevention, plus the drug utilization to reduce the desperation feeling and the abstinence symptoms, in such way to make the smoker handle the smoking cessation in a better way ${ }^{(9,14)}$. A study shows that the nicotine replacement therapy increases the abstinence proportion in around $50 \%{ }^{(15)}$.

It is recommended to use some special moments to encourage smoking cessation, such as pregnancy and hospitalization period, as well as adopt distinct approaches, according to the age group ${ }^{(16)}$. It is also important to prepare the smoker's social environment, so that family, friends and co-workers are able to help ${ }^{(9)}$.

Based on the interviews, it is possible to realize the participation of health professionals from different areas (physicians, nurses, dentists) and the population in general is required in the implementation of programs to support smoking cessation. It involves considering this habit as a chronic disease, which may also involve remission and recurrence phases, identifying factors that lead to restart to better prepare them for the next cessation attempt.

- Specific course and support groups

Participating in courses and/or support groups was identified as an efficient strategy to achieve smoking cessation.

I guess the group helps a lot, because the exchanges of experiences are very important. One old woman went out in the rain to buy cigarettes..., she was very ashamed, only smokers understand that ... E9F9

I didn't know all details involved in quitting smoking, I knew them in the group. If you thought of stopping smoking, look for a group that knows how to help. E10F10

First, it's important to make a personal decision and then look for support, either in groups, individual therapy, or with friends, because it's more difficult alone. Sharing experiences is important and I recommend it, as I guess it matches what we are looking for, in terms of information, benefits, you have support on the best way to do it ... E14F5

An important aspect to a nicotine-dependent person is the difficulty to explain to others how he/ she feels. According to the declarations, only smokers understand the difficulty to cease smoking. To them, the participation in support groups is special because their members experience the same problem, have the same difficulties and needs. According to the declarations, the participation in courses and support groups seems to have been effective in terms of providing orientations to the smoker, showing ways to follow and promoting their will to cease smoking. 
- Family, social and spiritual support

Stopping smoking does not seem to have been an easy experience; to overcome it, family, social and spiritual support was considered as important by the interviewees. Family is the center of support and encouragement, where the smoker feels secure and can express his/her fears and receive affection that will help him/her face the difficulties. As noticed in the declarations, this support was present and was reported as an important mobilizing factor.

My grandson was 6 years old. He saw campaigns on TV and used to say: 'Grandma, have you noticed TV is saying cigarette kills?' That hurt me inside... He said he didn't want me to die. I kept that inside me and it helped. E6F10

I guess the difference is in the comfort given, in making people who live with the smoker help him/her stop smoking ... E7F10

I was smoking on the street, under a tree, enjoying my cigarette, then my son came to me and said: 'Mom, are you still smoking? ... Don't you understand that with that you will shorten your time with us? ... I really want you to stay much longer with $m e^{\prime}$... This was an argument that nobody had used, of love, affection. E13F6

The support of family, friends, children and other smokers was determinant to smoking cessation. This way, it is important that close people show interest in helping, provide support and get involved in the situation, helping them overcome the difficulties. According to the interviewees, smokers played an important role in this process, as they did not smoke near them during the cessation process.

For some interviewees, beliefs also seem to have been an important influence on smoking cessation.

I am spiritualized... There's a moment we can't do it, I guess we even have to pray and ask. Praying helps a lot. E3F1O

I used to meditate a lot. I believe the will to smoke lasts some seconds... I've learned how to educate myself in this sense. E4F7

The declarations show the need for support to get to cease smoking and respect the person's individual pace to cease smoking.

\section{FINAL CONSIDERATIONS}

The results of this study suggest that the smoker's determination to cease smoking and the support from several segments of the society influenced smoking cessation.

The determination to cease smoking was required to enable the behavior change and made smokers keep their decision, despite the adversities, allowing to understand the smoker needs to be aware of the responsibility for his/her health.

The decision to stop smoking would have been motivated, according to the interviewees, by influences of other people, such as relatives, friends and social communication means, and, for this reason, the importance of the participation from all community in the process. The need for special emphasis on motivation should also be noted, without which the participants would not have been able to cease smoking and keep themselves abstinent.

In addition, the professional, family, social and spiritual supports played a relevant role in promoting smoking cessation. Findings allow to infer the importance of health professionals and the society to understand how difficult stopping smoking is and create affective and technical conditions that strengthen the motivation to behavior change, without which smokers will not be able to keep themselves abstinent. For this purpose, it is essential for the multidisciplinary team to include the family in this process, listening to their needs, in order to enable the family to contribute to the treatment. Findings also alert to the need for health team training, availability of effective smoking cessation programs and access to drugs.

Since motivation is an essential factor, one of the actions of health professionals is to always provide orientations to prevent, for example, smokers or his/her family to leave a physician office or hospitalization without the information that smoking causes health harms, even if the individual does wish to cease. This action helps mobilize the smoker and favor his/her behavior change.

Based on the declarations, it is believed that one of the health education alternatives to be performed by the professionals in order to reduce smoking prevalence is to value the participation of smokers in abstinence, therapeutic groups, as models of identification and successful strategy references, as a significant contribution to the implementation of education and health policies for smoking prevention.

\section{ACKNOWLEDGEMENTS}

We would like to thank professors Anna Luz and José Roberto Goldim and nursing student Giordana Motta. We also thank FAPERGS and CNPq/UFRGS for the scientific funding support and FIPE of the HCPA for the financial support. 


\section{REFERENCES}

1. World Health Organization [homepage on the Internet]. Genebra: WHO; 2004 [cited 2006 Jan 30]. The future. Available from: http://www.who.int/tobacco/en/atlas38.pdf: 2. Repace J, Lowrey A. Indoor air pollution, tobacco smoke and public health. Science $1980 ; 208(2): 464-72$.

3. Cinciprini PM, Hecht SS, Henningfield JE, Manley MW, Kramer BS. Tobacco addiction: implications for treatment and cancer prevention. J Natl Cancer Inst 1997;86:1852-67.

4. Echer IC. Fatores de sucesso no abandono do tabagismo [tese]. Porto Alegre (RS): Faculdade de Medicina/ Universidade Federal do Rio Grande do Sul; 2006.

5. Polit $D$, Beck $C T$, Hungler BP. Fundamentos em pesquisa em enfermagem. 5. ed. Porto Alegre (RS): ARTMED; 2004. 6. Fagerström KO, Schneider NG, Lunell E. Effectiveness of nicotine patch and nicotine gum as individual versus combined treatment for tobacco withdrawal simptoms. Psychopharmacology 1993;111:271-7.

7. Bardin L. Análise de conteúdo. Lisboa: Edições 70; 1977.

8. Dórea AJP, Botelho C. Fatores dificultadores da cessação do tabagismo. J Bras Pneumol 2004 agosto;30(2):41-6.

9. Meirelles RHS, Gonçalves CMC. Abordagem cognitivocomportamental do fumante. J Bras Pneumol 2004 agosto;30(2):30-5.

10. Brasil, Ministério da Saúde, Instituto Nacional de Câncer, Coordenação de prevenção e Vigilância. Abordagem e tratamento do fumante: Consenso 2001. Rio de Janeiro (RJ): INCA; 2001.

11. Kirchenchtejn C, Chatkin JM. Dependência da nicotina. J Bras Pneumol 2004 agosto;30(2):11-8.

12. Stuchi RAG, Carvalho EC. Crenças dos portadores de doença coronariana, segundo o referencial de Rokeach, sobre o comportamento de fumar. Rev Latino-am Enfermagem 2003 fevereiro; 11(1):74-9.

13. Miller WR, Rollnick S. Entrevista Motivacional: preparando as pessoas para a mudança de comportamentos adictivos. Porto Alegre (RS): ARTMED; 2001.

14. Viegas CCA, Reichert J. Tratamento medicamentoso. J Bras Pneumol 2004 agosto; 30(2):36-40.

15. Otero B, Perez CA, Szklo M, Esteves GA, Pinho MM, Szklo AS, et al. Ensaio clínico randomizado: efetividade da abordagem cognitivo-comportamental e uso de adesivos transdérmicos de reposição de nicotina, na cessação de fumar, em adultos residentes no Município do Rio de Janeiro, Brasil. Cad Saúde Pública 2006;22(2):439-49.

16. Pereira LFF. Abordagens de grupos especiais: pacientes hospitalizados. J Bras Pneumol 2004 agosto;30(2):62-4. 